\title{
UJI EFEK PERASAN DAUN BAYAM MERAH (Amaranthus tricolor) TERHADAP KADAR HEMOGLOBIN PADA TIKUS WISTAR (Rattus norvegicus)
}

\author{
${ }^{1}$ Esther Ariny Rumimper \\ ${ }^{2}$ Jimmy Posangi \\ ${ }^{2}$ Jane Wuisan
}

\author{
${ }^{1}$ Kandidat Skrispi Fakultas Kedokteran Universitas Sam Ratulangi Manado \\ ${ }^{2}$ Bagian Farmakologi Fakultas Kedokteran Universitas Sam Ratulangi Manado \\ Email: estherrumimper@gmail.com
}

\begin{abstract}
Medicinal herbs has been cultivated and utilized as treatments for diseases since ancient times. Among these medicinal herbs is redleaf amaranth that is mainly utilized for treatment of anemia. This study aims to determine the effect of redleaf amaranth decoction on Wistar rat's hemoglobin level. This is an experimental study performed on Wistar rats. Readleaf amaranth was blend with water and its decoction was administered orally. Hemoglobin level was measured using blood sample taken directlu from the heart of the study animals. The result shows that redleaf amaranth decoction plays a role in elevating hemoglobin level on Wistar rats.
\end{abstract}

Keywords: Redleaf amaranth, Hemoglobin

\begin{abstract}
Abstrak: Masyarakat pada umumnya banyak mengenal bahkan memanfaatkan tanaman yang diyakini bisa menyembuhkan beberapa penyakit. Salah satu tumbuhan yang sering di gunakan adalah bayam merah yang dianggap bisa mengobati kurang darah. Penelitian ini bertujuan untuk mengetahui efek dari pemberian perasan daun bayam merah terhadap kadar hemoglobin tikus Wistar. Penelitian ini merupakan penelitian eksperimental laboratorik yang dilakukan terhadap uji berupa tikus Wistar. Daun bayam merah di blender dengan air dan perasannya diberikan secara oral terhadap hewan uji. Kadar hemoglobin diukur menggunakan sampel darah yang diambil langsung dari jantung Wistar. Hasil penelitian ini menunjukkan bahwa perasan daun bayam merah dapat meningkatkan kadar hemoglobin.
\end{abstract}

Kata Kunci: Daun Bayam Merah, Hemoglobin.

Salah satu masalah kesehatan masyarakat di Indonesia adalah anemia. Anemia berarti kekurangan sel darah merah, yang dapat disebabkan oleh hilangnya darah yang terlalu cepat atau karena terlalu lambatnya produksi sel darah merah. ${ }^{1}$

Penggunaan tanaman sebagai obat suatu penyakit sudah dilakukan sejak zaman nenek moyang kita, salah satu tanaman yang sering digunakan adalah Bayam Merah. Tanaman bayam berasal dari Amerika, mudah tumbuh dan tersebar di daerah tropis dan sub tropis di seluruh dunia. Di Indonesia sendiri bayam dapat tumbuh sepanjang tahun dan ditemukan pada ketinggian 5 $2.000 \mathrm{~m}$ dpl, tumbuh di daerah panas dan dingin, tetapi tumbuh lebih subur di dataran rendah pada lahan terbuka yang udaranya agak panas.

Makanan berserat seperti bayam, baik bagi penderita kanker usus besar, kencing manis, kolesterol, untuk menurunkan berat badan dan juga bayam merah dapat meningkatkan kerja ginjal serta membersihkan darah sehabis bersalin, tekanan darah rendah dan kurang darah. ${ }^{2}$ 
Masyarakat Minahasa telah lama mempercayai bahwa bayam merah dapat meningkatkan kadar hemoglobin darah. Berdasarkan hal-hal tersebut di atas, maka penulis tertarik untuk mengetahui bagaimana efek perasan daun bayam merah terhadap kadar hemoglobin pada tikus wistar. Terdapat tiga varietas bayam yang termasuk ke dalam Amaranthus tricolor, yaitu bayam hijau biasa, Bayam Merah (Blitum rubrum), yang batang dan daunnya berwarna merah, dan Bayam Putih (Blitum album), yang berwarna hijau keputihputihan. Daun dan batang bayam merah mengandung cairan berwarna merah. Selain A. tricolor, terdapat bayam jenis lain, seperti bayam kakap (A. hybridus), bayam duri ( $A$. spinosus), dan bayam kotok/bayam tanah (A. blitum). Jenis bayam yang sering dibudidayakan adalah $A$. tricolor dan $A$. hybridus sedangkan jenis bayam lainnya tumbuh liar. ${ }^{3}$

\section{TUJUAN PENELITIAN}

Penelitian ini dilakukan untuk mengetahui efek dari pemberian perasan daun bayam merah terhadap kadar hemoglobin pada tikus wistar.

\section{METODE}

Penelitian dilakukan dengan menggunakan metode eksperimental. Penelitian dilakukan pada bulan Agustus 2011 sampai Januari 2013. Dalam penelitian ini digunakan 14 ekor tikus Wistar jantan yang di bagi dalam 4 kelompok. Daun bayam merah dijadikan perasan dan diberikan secara oral untuk melihat efeknya terhadap jumlah hemoglobin. Dengan pemberian daun bayam merah diharapkan dapat meningkatkan kadar hemoglobin pada tikus wistar. Sampel berupa daun bayam merah yang dipetik dari kebun, daun yang di ambil adalah daun yang masih segar untuk dipakai dalam pembuatan perasaan. Daun bayam merah yang telah diambil, ditimbang seberat 100 gram kemudian dicampurkan air 100 cc lalu diblender sampai halus. Setelah itu diperas airnya menggunakan kertas saring, lalu diambil hasil perasan daun bayam merah.
Daun bayam merah yang dipakai pada manusia 2 genggam dicampurkan dengan air sebanyak 1 gelas air, lalu diblender sampai halus dan diperas/disaring. Cara menggunakan : diminum $1 \times$ sehari $( \pm 250$ cc) selama 1 minggu. $^{5}$ Perlakuan tersebut diatas diberikan pada orang dewasa dengan berat rata-rata $50 \mathrm{~kg}$, sedangkan untuk jumlah dosis yang diberikan pada tikus wistar dengan berat badan $200 \mathrm{~g}$ yaitu:

$$
\begin{gathered}
200 / 50.000 \text { x } 250 \mathrm{cc}=1 \mathrm{cc} / \text { tikus } \\
\text { wistar }
\end{gathered}
$$

Perlakuan pada tikus wistar dibagi dalam 4 kelompok dimana kelompok I tidak diberi perlakuan apa-apa selain diberi pakan, kelompok II diberi dosis 0,5cc, kelompok II diberi dosis 1cc, dan kelompok IV diberi dosis 2cc. Pemberian dilakukan 1x sehari selama 28 hari.

\section{HASIL PENELITIAN DAN BAHASAN}

Daun bayam merah yang dijadikan bahan penelitian diambil dari kebun di daerah Kawangkoan Kabupaten Minahasa. Sample yang dipakai semuanya berasal dari satu kebun yang sama. Daun bayam merah yang diambil yaitu semua daun bayam merah yang masih segar.

Bayam mengandung protein (asam amino, lisin, dan methionine), lemak, karbohidrat, serat, mineral (kalsium, kalium, magnesium, mangan, fosfor, besi dan zink), vitamin (A, B1, B2, dan C), karoten, niasin, folat, amarantin, rutin, purin, tannin, dan asam oksalat. Pigmen pada bayam hijau kaya akan klorofil yang termasuk dalam golongan flavonoid (sering dinamakan bioflavonoid). Klorofil berkhasiat antioksidan yang berfungsi menetralkan gangguan radikal bebas sehingga mencegah DNA sel bermutasi menjadi ganas. Klorofil juga berkhasiat mempercepat penyembuhan luka. Adapun bayam merah mengandung pigmen merah menandakan kandungan flanovoid-nya cukup tinggi dan berkhasiat antioksidan. 4

Berdasarkan hasil penelitian didapatkan bahwa pengambilan sampel darah dari kelompok II yang diberi perasan daun bayam merah sebanyak 0,5cc pada minggu I 
yaitu 17,2 $\mathrm{mg} / \mathrm{dl}$, minggu II menjadi 17,8 $\mathrm{mg} / \mathrm{dl}$, minggu III menjadi 18,4 $\mathrm{mg} / \mathrm{dl}$ dan minggu IV menjadi 18,8 mg/dl.

Pada kelompok III diberi perasan daun bayam merah sebanyak 1cc pada minggu I yaitu $17,8 \mathrm{mg} / \mathrm{dl}$, minggu II menjadi 18,8 $\mathrm{mg} / \mathrm{dl}$, minggu III menjadi $19,0 \mathrm{mg} / \mathrm{dl}$ dan minggu IV menjadi 19,6 mg/dl.

Pada kelompok III diberi perasan daun bayam merah sebanyak 2cc pada minggu I yaitu 18,0 mg/dl, minggu II menjadi 19,0 mg/dl, minggu III menjadi 19,2 mg/dl dan minggu IV menjadi 19,8 mg/dl.

Berdasarkan hasil penelitian yang dilakukan pada tikus wistar dapat diperoleh hasil bahwa semakin tinggi pemberian dosis perasan daun bayam merah maka semakin tinggi kadar hemoglobin dalam darah.

Penelitian yang dilakukan oleh Ernawati Santoso, Fakultas Farmasi, (WIDMAN, 1986) infus daun bayam merah $30 \%$ yang diberikan per oral pada kelinci terjadi peningkatan kadar besi serum, hemoglobin dan hematokrit pada kelinci yang dibuat kurang darah (anemia).

\section{SIMPULAN}

Dari penelitian ini dapat disimpulkan terjadi peningkatan kadar hemoglobin melalui perasan daun bayam merah (amaranthus tricolor) yang diberikan pada tikus wistar (rattus norvegicus).

\section{SARAN}

1. Perlu dilakukan penelitian lebih lanjut mengenai efek perasan daun bayam merah terhadap kadar hemoglobin dengan penambahan jumlah hewan coba.

2. Perlu penelitian lebih lanjut mengenai zat-zat yang terkandung dalam perasan daun bayam merah.

3. Perlu dilakukan penelitian lebih lanjut tentang efek samping dari pemberian perasan daun bayam merah.

\section{DAFTAR PUSTAKA}

1. Hembing. Pemanfaatan Herbal Untuk Kesehatan \& Pengobatan Penyakit. Diunduh dari: $\quad$ http://imunisasihalal.wordpress. com/2008/04/08/hembing-pemanfaatanherbal-untuk-kesehatan-pengobatanpenyakit/. Diakses 28 Juli 2011.

2. Anynomous. Tanaman obat bayam Informasi dan Tips. Diunduh dari: http://informasidantips.com/tanaman-obatbayam/ Diakses 8 September 2008.

3. Raina. Ensiklopedi Tanaman Obat untuk Kesehatan. Yogyakarta: Absolut, 2011; h.40-41.

4. Dalimartha S, Adrian F. Khasiat Buah dan Sayur. Jakarta: Penebar Swadaya, 2011; h.100-103.

5. Siddig J. Rahasia, Khasiat \& Manfaat Bumbu dapur, rempah-rempah dan sayursayuran. Yogyakarta: Surya Media, 2010; h.60. 